\title{
Potentiometric Determination of Fluoride in Vinegars
} \author{
Jaudenes ${ }^{1}$, Antonio Burgos ${ }^{2}$ and Consuelo Revert ${ }^{3}$ \\ ${ }^{1}$ Department of Toxicology, Universidad de La Laguna, Spain \\ ${ }^{2}$ Department of Medicine Preventive and Public Health, Universidad de La Laguna, Spain \\ ${ }^{3}$ Department for Physical Medicine and Pharmacology, Universidad de La Laguna, Spain
}

Inmaculada Rodríguez ${ }^{1}$, Arturo Hardisson ${ }^{1}$, Angel J Gutiérrez ${ }^{1 *}$, Carmen Rubio ${ }^{1}$, Soraya Paz ${ }^{1}$, Juan Ramón

Submission: November 11, 2017; Published: February 12, 2018

*Corresponding author: Angel J Gutiérrez, Department of Toxicology, Universidad de La Laguna, Spain, Tel: +34 61017238; Fax: +34-922626479;

Email: ajguti@ull.es

Abstract

The excessive intake of fluoride causes several diseases as dental and skeletal fluorosis. The fluoride intake is from the diet, vinegar is liquid widely used as condiment and food preservative. To determine the concentration of fluorides in different types of vinegars and to compare the content with the concentrations found in wines. A total of 31 samples of vinegars were analyzed by potentiometric determination using a fluoride selective ion electrode. The fluoride concentrations found in all samples were less than $1 \mathrm{mg} / \mathrm{L}$, which is the recommended limit for fluoride in wines, with an average concentration of $0.39 \pm 0.17 \mathrm{mg} / \mathrm{L}$. The fluoride content is not very high. The consumption of vinegar is low because it is a condiment; however, it is widely used as a preservative so it would of interest to study the transferability of fluoride from vinegar to the food preserved with it.

Keywords: Vinegar; Food preservative; Fluoride; Potentiometry; Fluoride selective electrode

\section{Introduction}

Vinegar, whose name comes from the Latin acrid vinum meaning sour wine, is a sour-tasting liquid widely used as a condiment and food preservative. The chemical composition of vinegar depends on the type in question, for example, the content of acetic acid (ethanoic acid) in water may range from 5-20\%, and may contain small amounts of tartaric acid (2,3-Dihydroxybutanedioic acid) and citric acid (2-hydroxypropane-1,2,3-tricarboxylic acid) [1].

There are different types of vinegars, with vinegars made from wine being the most consumed type in Europe. Vinegar was traditionally obtained from wines that went sour and was produced by two fermentation processes. Alcoholic fermentation (conversion of sugar into alcohol) takes place in the first step and this fermentation is carried out by bacteria such as Saccharomyces cerevisae [2], and the second step consists of the acetic fermentation of the alcohol performed by the bacteria Mycoderma aceti [1,3]. At present, the process of obtaining vinegar is by adding a culture of bacteria to the wine from which you want to obtain the vinegar; this process takes place over a period of 24 - 36 hours. The reactions to obtain the vinegar are as follows:
1. $\mathrm{C}_{6} \mathrm{H}_{12} \mathrm{O}_{6} \rightarrow 2 \mathrm{CH}_{3} \mathrm{CH}_{2} \mathrm{OH}+2 \mathrm{CO}_{2}$

2. $\mathrm{CH}_{3} \mathrm{CH}_{2} \mathrm{OH}+\mathrm{O}_{2} \rightarrow \mathrm{CH}_{3} \mathrm{COOH}+\mathrm{H}_{2} \mathrm{O}$

However, there is another method of obtaining vinegar, in which the bacteria are not added to the wine, but are kept in direct contact with the surface of the wine. This process is slower [3]. This process produces higher quality vinegars with better organoleptic characteristics.

As for apple cider vinegar (cider), this type of vinegar is obtained following the same process as wine vinegar [4,5]. Apple cider vinegar may also have beneficial effects on diseases such as arthritis, obesity and asthma [6], which may increase the consumption of this vinegar.

Vinegar may contain fluorides because it is produced from wine. Fluoride in wines comes mainly from irrigated water, volcanic soils, as a result of its storage in cement tanks or the use of antiseptics and anti ferments containing fluoride. In the same way, apple cider vinegar contains the fluoride in the apples originating in the soil and irrigated water.

Fluoride is necessary as it plays an important role in the mineralization of teeth and bones, activation of enzymes, 
prevention of caries, etc. However, at high concentrations, fluoride is toxic and produces numerous detrimental effects on human health such as dental and bone fluorosis $[7,8,9]$. Numerous institutions have set recommended values for fluoride intake, e.g., the European Food Safety Authority (EFSA) set a Recommended Daily Intake (RDI) of 4 and $3 \mathrm{mg} /$ day for adult men and women, respectively [10]. On the other hand, the Institute of Medicine, Food and Nutrition Board has established a maximum allowable daily intake (ADI) of $10 \mathrm{mg}$ /day for adults [11].

Although vinegar is not consumed in large quantities, it is widely used as a food preservative, which is why; consequently, the concentration of fluoride in these foods can increase. For this reason, a total of 31 samples of vinegars of different types and origins have been analyzed in order to know the fluoride content and compare this with the fluoride concentrations obtained in wines.

\section{Material and methods}

\section{Samples}

A total of 31 samples of vinegar bought in different shopping centers on the island of Tenerife have been analyzed. They are as follows:

1. 16 red wine vinegars (red, aging, garlic, fine herbs, tarragon, garnacha grape).

2. 10 white wine vinegars (white, aged, sherry, reserve sherry, cava and essence of tarragon).

3. 5 apple cider vinegars.

\section{Solutions preparation and equipment and material used}

The following solutions were prepared for the fluoride determination:

1. $10^{-1} \mathrm{M}$ fluoride solution: prepared by dissolving $2.210 \mathrm{~g}$ of $\mathrm{NaF}$, previously dried in an oven at $120{ }^{\circ} \mathrm{C}$ for 2 hours, flushing in a $1 \mathrm{~L}$ plastic volumetric flask in distilled water (conductivity $0.06 \mu \mathrm{S} / \mathrm{cm}$ ).

2. Buffer solution of TISAB-CDTA (Total Ionic Strength Adjustment Buffer-1,2-diamino-cyclohexanetetraacetic acid): $58 \mathrm{~g}$ of $\mathrm{NaCl}$ p.a. (Sigma Aldrich, Germany) and $57 \mathrm{ml}$ of glacial acetic acid p.a. (Honeybell Fluka, Germany) were added to $500 \mathrm{ml}$ of distilled water in a 1-liter beaker add. The contents were stirred until complete dissolution and $4 \mathrm{~g}$ of CDTA p.a. (Sigma Aldrich, Germany) (1,2-diaminocyclohexanetetraacetic acid) were then added. Stirring was continued until the solids completely dissolved and the solution was finally adjusted to $\mathrm{pH}$ 5.5-5.5 with $50 \% \mathrm{NaOH}$ p.a.

Equipment and material used for the fluoride determination:

Potentiometer with fluoride selective ion electrode (brand CRISON 9655 ) and reference electrode Ag/AgCl (CRISON 52-
41) and a pH meter (CRISON GLP 22) with pH electrode of high alkalinity (CRISON 5204) and magnetic stirrer (SELECTA) with stirring magnet (Figure 1). The measures were recorded using polyethylene beakers.

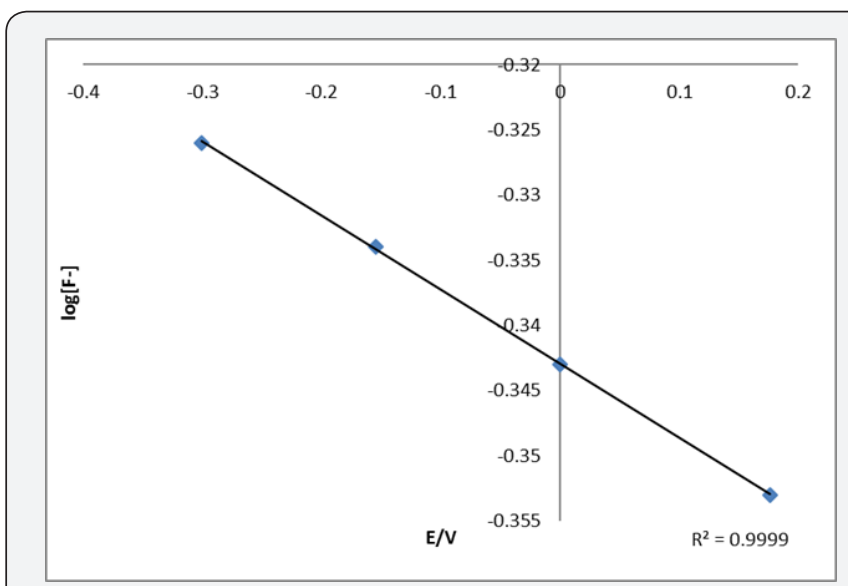

Figure 1: Response of Fluoride ion selective electrode to fluoride ions at $\mathrm{pH}=5.0$.

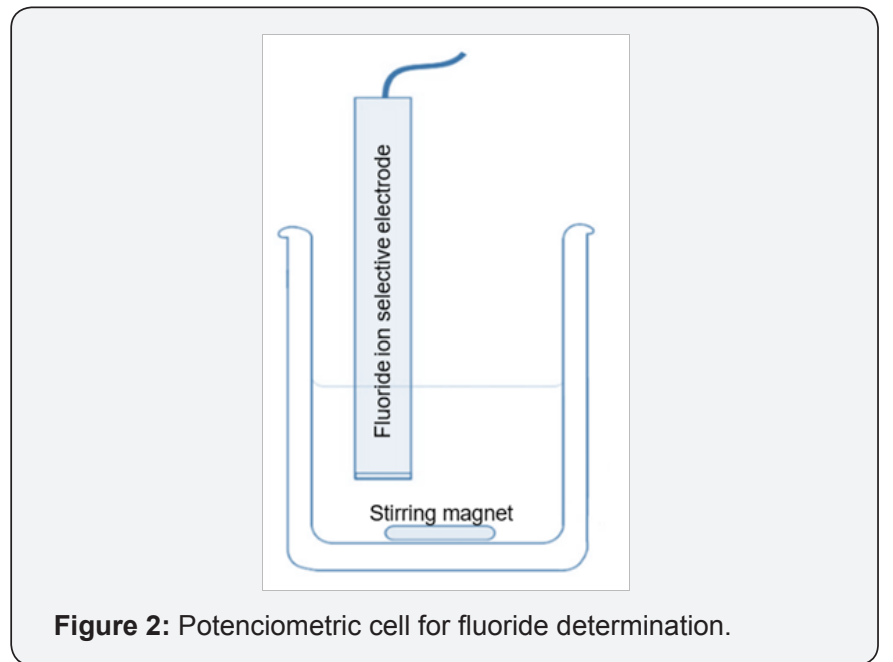

Figure 2 shows the response given in the fluoride ion determination at $\mathrm{pH}=5.0$ by using the fluoride ion selective electrode. The theoretical Nerstian slope for monovalent cations was followed in order to assure the accuracy of the method. The correlation coefficient was 0.999 .

\section{Measurement of the fluoride concentration in vinegar samples}

The method is based on the measurement of the potential before and after addition of a known amount of fluoride to a mixture of sample/and conditioning solution. The following formula has been used for the fluoride concentration:

$$
\left[\mathrm{F}^{-}\right](\mathrm{Mg} / \mathrm{L})=\mathrm{V}_{\mathrm{a}} \bullet \mathrm{C} /\left[\mathrm{VO} \bullet\left(10^{\Delta \mathrm{E} / \mathrm{s}-1}\right)\right]
$$

$\mathrm{V}_{\mathrm{a}}$ : added volume $(\mathrm{mL}) ; \mathrm{C}$ : concentration $(\mathrm{mg} / \mathrm{L}) ;$ Vo: sample volume analyzed (milliliters); $\Delta \mathrm{E}$ : potential increase (millivolts); S: electrode slope (millivolts).

Before measuring the sample potential, the apparatus was calibrated using two commercial solutions (CRISON) of pH 7 and 
$\mathrm{pH} 4$, and a $\mathrm{pH}$ meter. It is necessary to use a conditioning solution or buffer to prevent interferences in the potential measurement. The buffer solution used in this study was the solution of TISABCDTA, which was chosen according to the studies conducted by García et al. [12] where this solution was reported to be the one with the best response.

Because of the acidity of the vinegar, it is necessary to adjust the $\mathrm{pH}$ before the potential measurements. In order to do this, $50 \mathrm{ml}$ of vinegar and $10 \mathrm{ml}$ of $4 \mathrm{M} \mathrm{NaOH}$ are placed in a polyethylene cup to adjust the $\mathrm{pH}$. Afterwards, $50 \mathrm{ml}$ of $\mathrm{pH}$ adjusted vinegar was taken and $5 \mathrm{ml}$ of TISAB-CDTA buffer solution were added. The fluoride electrode and the reference electrode were then introduced into the solution and the potential difference was measured, with constant stirring throughout. Once the measurement is stabilized, an aliquot of F-10-3M standard solution was added, and the potential was measured again.

\section{Results and Discussion}

(Table 1) shows the concentrations of fluoride (mg/l) obtained for each sample analyzed, as well as the data concerning trademark, acidity, type of vinegar, origin and packaging. The lowest concentration of fluoride was found in a white wine vinegar from Logroño, whose concentration was $0.12 \mathrm{mg} / \mathrm{l}$. Whereas, the highest concentration was in a red wine sherry vinegar from Seville, with a concentration of $0.97 \mathrm{mg} / \mathrm{l}$. The mean concentration of all vinegars, without distinguishing their origin, was $0.39 \pm 0.17 \mathrm{mg} / \mathrm{l}$.

Table 1: Concentration of fluoride (mg/L), origin, type of container and vinegar, acidity and trademark of the analyzed vinegars.

\begin{tabular}{|c|c|c|c|c|c|}
\hline Trademark & Type of vinegar & Container & Origin & Acidity & {$[\mathrm{F}-](\mathrm{mg} / \mathrm{L})$} \\
\hline Adelina & From red wine & Glass & Tenerife & $6^{0}$ & 0.41 \\
\hline Borges & From red wine with garlic & Glass & Lérida & $6^{0}$ & 0.46 \\
\hline Borges & From Apple cider & Glass & Lérida & $5^{\mathrm{o}}$ & 0.43 \\
\hline Borges & $\begin{array}{l}\text { From white wine with essence of } \\
\text { tarragon }\end{array}$ & Glass & Lérida & $6^{0}$ & 0.31 \\
\hline Borges & From cava white wine de cava & Glass & Lérida & $7^{\circ} \stackrel{0}{2}$ & 0.48 \\
\hline Borneo & From White sherry wine & Glass & Seville & $8^{\circ}$ & 0.45 \\
\hline Carbonell, procer & From red wine & PET & Córdoba & $6^{0}$ & 0.55 \\
\hline Femua & From wine white & Glass & Logroño & $6^{0}$ & 0.12 \\
\hline Lau & From White sherry wine & Glass & Toledo & $7^{\circ} \stackrel{0}{2}$ & 0.28 \\
\hline Lau & From apple & Glass & Toledo & $5^{\underline{o}}$ & 0.33 \\
\hline Lau & From aged White wine & Glass & Toledo & $7.5^{\circ}$ & 0.27 \\
\hline L'estornell & From red garnacha wine & Glass & Cataluña & - & 0.25 \\
\hline Louit & From balsamic wine & Glass & Córdoba & $6^{0}$ & 0.55 \\
\hline Louit & From Apple cider & Glass & Córdoba & 5 o & 0.3 \\
\hline Louit & From red wine with natural garlic & Glass & Córdoba & $6^{0}$ & 0.59 \\
\hline Prima Lau & From red wine & Glass & Toledo & $6^{\circ}$ & 0.25 \\
\hline Prima Lau & From wine white & Glass & Toledo & $6^{0}$ & 0.38 \\
\hline Ybarra & From White sherry wine & Glass & Seville & $7^{\circ} \stackrel{0}{2}$ & 0.97 \\
\hline Ybarra & From apples & Glass & Seville & $5^{0}$ & 0.55 \\
\hline Ybarra & From aging red wine & Glass & Seville & $8^{\circ}$ & 0.3 \\
\hline Ybarra & From red wine & PET & Seville & $6^{0}$ & 0.66 \\
\hline Ybarra & From red wine & PET & Seville & $6^{0}$ & 0.19 \\
\hline Ybarra & From red wine with fine herbs & Glass & Seville & $6^{0}$ & 0.45 \\
\hline Ybarra & From red wine with tarragon & Glass & Seville & $6^{0}$ & 0.52 \\
\hline Hacendado & From White wine & PET & Murcia & $6^{0}$ & 0.33 \\
\hline Hacendado & From white sherry wine & Glass & Murcia & $6^{\circ}$ & 0.32 \\
\hline Hacendado & From red wine with garlic & Glass & Murcia & $6^{0}$ & 0.22 \\
\hline Hacendado & From Apple cider & Glass & Murcia & $5^{\circ}$ & 0.35 \\
\hline Hacendado & From red wine with tarragon & Glass & Murcia & $6^{0}$ & 0.21 \\
\hline Hacendado & From aging red wine & Glass & Murcia & $8^{\circ}$ & 0.25 \\
\hline Hacendado & From red wine & PET & Murcia & $6^{0}$ & 0.33 \\
\hline
\end{tabular}




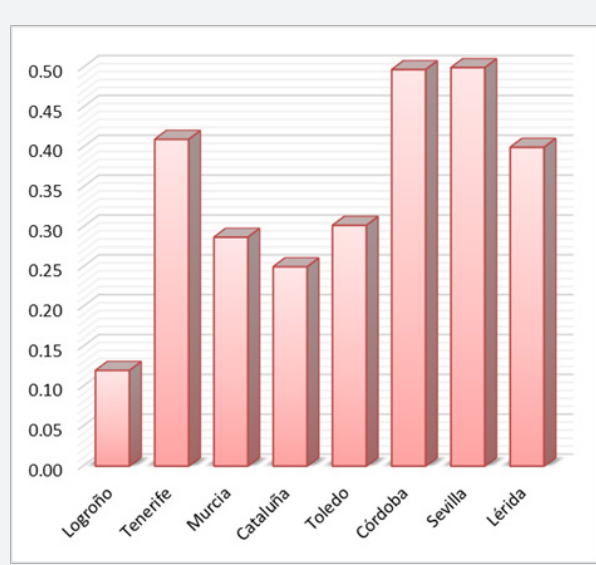

Figure 3: Mean concentration of fluoride (mg/l) depending on the origin of the vinegar.
(Figure 3) shows the average concentrations of fluoride (mg/l) depending on the origin of the vinegar. The vinegars from Seville and Córdoba had the highest average concentrations of fluoride. The vinegars from Logroño and Catalonia had the lowest concentrations of fluoride.

As for the type of vinegar, the same mean concentration of fluoride was found for each type, and this figure was $0.39 \mathrm{mg} / \mathrm{l}$.

\section{Comparison of vinegar concentration with other authors}

(Table 2) shows the fluoride concentrations (mg/l) obtained by the other consulted authors for vinegar samples. Lapa et al. [13] reported higher fluoride concentrations than those found in the present study. Whereas the mean concentration obtained by García et al. [12] is greater than those obtained here.

Table 2: Comparison of fluoride content (mg/l) found by other authors in vinegar samples.

\begin{tabular}{|c|c|c|c|}
\hline Origin & Trademark/Type & [F-] (mg/L) & Reference \\
\hline \multirow{9}{*}{ Portugal } & Campestre Branco/White wine & $1.42 \pm 0.07$ & \multirow{9}{*}[14]{} \\
\hline & Campestre Red/Red wine & $0.54 \pm 0.04$ & \\
\hline & Cristal/White wine & $1.45 \pm 0.02$ & \\
\hline & Guloso Branco/White wine & $3.99 \pm 0.05$ & \\
\hline & Guloso Red/Red wine & $1.37 \pm 0.07$ & \\
\hline & Leziria & $1.48 \pm 0.04$ & \\
\hline & Pataxo & $2.96 \pm 0.07$ & \\
\hline & Salata & $1.41 \pm 0.02$ & \\
\hline & Vila Flor & $1.39 \pm 0.01$ & \\
\hline Spain & - & 0.52 & [7] \\
\hline \multirow{11}{*}{ Spain } & Adelina/Red wine & 0.41 & \multirow{11}{*}{ The present study, 2016} \\
\hline & Borges/Wine and cider & 0.42 & \\
\hline & Borneo/Red wine & 0.45 & \\
\hline & Carbonell/Red wine & 0.55 & \\
\hline & Femua/White wine & 0.12 & \\
\hline & Hacendado/Wine and cider & 0.29 & \\
\hline & L'estornell/Red wine & 0.25 & \\
\hline & Lau/Wine and cider & 0.29 & \\
\hline & Louit/Wine and cider & 0.48 & \\
\hline & Prima Lau/Wine & 0.32 & \\
\hline & Ybarra/Wine and cider & 0.52 & \\
\hline
\end{tabular}

Comparison of the concentration of vinegar obtained with wines and ciders

(Table 3) shows the mean concentrations of fluoride $(\mathrm{mg} / \mathrm{l})$ reported by other authors in wine samples. The mean concentration obtained here for wine and cider vinegar $(0.39$ $\mathrm{mg} / \mathrm{l}$ ) was higher than the mean concentrations reported in wine samples by Bernal et al. [14], De Baenst et al. [15], Deschreider et al. [16], Hardisson [17], Hidalgo et al. [18], Martínez Rincón et al. [19], Pérez-Olmos et al. [20], Pérez-Olmos et al. [21], Rodríguez Gómez et al. [22] and Paz et al. [9]. 
Table 3: Comparison of fluoride content $(\mathrm{mg} / \mathrm{L}$ ) obtained by other authors in wines and ciders.

\begin{tabular}{|c|c|c|}
\hline Type & {$\left[F^{-}\right](\mathbf{m g} / \mathbf{l})$} & Reference \\
\hline Wine & 0.13 & {$[1]$} \\
\hline Wine & 0.17 & {$[3]$} \\
\hline Wine & 0.18 & {$[4]$} \\
\hline Wine & 0.2 & {$[9]$} \\
\hline Wine & 0.31 & {$[10]$} \\
\hline Wine & 1.39 & {$[15]$} \\
\hline Wine & 0.25 & {$[16]$} \\
\hline Wine & 0.83 & {$[17]$} \\
\hline Wine & 0.28 & {$[20]$} \\
\hline Wine & 0.2 & {$[21]$} \\
\hline Wine & 0.15 & {$[23]$} \\
\hline Red wine & 0.12 & The present study, \\
\hline White wine & 0.15 & {$[19]$} \\
\hline Rosé wine & 0.13 & \\
\hline Red wine & 1.05 & {$[24]$} \\
\hline White wine & 2.02 & \\
\hline Wine vinegar & 0.39 & \\
\hline Apple vinegar & 0.39 & \\
\cline { 1 - 2 } & & \\
\hline
\end{tabular}

The concentration obtained in wine samples by Martín et al. [23], Moreno et al. [24] and USDA [25], was greater than that obtained in the present study for both types of vinegars.

\section{Evaluation of dietary intake}

Although vinegar is not a product that is consumed in large quantities, it is widely used as a food preservative. Therefore, it would be of interest to study the transfer of fluoride from vinegar used as a preserving liquid for food, as this could be a source of fluoride.

In addition, apple cider vinegar is consumed because of its possible beneficial properties. The Recommended Daily Intake (RDI) of apple cider vinegar is $30 \mathrm{ml}$, and therefore the fluoride intake from this type of vinegar would be 0.29 and $0.39 \%$ of the Recommended Daily Intake (RDI) for men and women, respectively.

\section{Conclusion}

The fluoride concentrations found in the vinegar samples analyzed are not very high, and therefore, taking into account the low consumption of vinegar, fluoride in vinegar does not pose any health risk. However, in cases where the vinegar is used as a preservative of other foods, it would be interesting to study the fluoride contribution in food preserved in vinegar.

\section{Conflict of Interests}

The authors declare that they have no conflicts of interest.

\section{References}

1. Ho CW, Lazim AM, Fazry S, Zaki UKHH, Lim SJ (2017) Varieties, production, composition and health benefits of vinegars: A review. Food Chem 221: 1621-1630

2. Dussap CG, Poughon L (2017) Current Development in Biotechnology and Bioengineering: Food and Beverages Industry. Academic Press, Amsterdam, Netherlands, pp. 263-279.

3. Paneque P, Morales ML, Burgos P, Ponce L, Callejón RM (2017) Elemental characterization of Andalusian wine vinegars with protected designation of origin by ICP-OES and chemometric approach. Food Control 75: 203-210.

4. Erazo RE, Reyna LM, Robles R, Huamán MAR (2001) Producción de vinagre de manzana por fermentación a escala piloto. Rev Per Quím Ing Quím 4(1): 67-72.

5. Villar A, Vadillo J, Santos JI, Gorritxategi E, Mabe J, et al. (2016) Cider fermentation process monitoring by Vis-NIR sensor system and chemometrics. Food Chem 221: 100-106.

6. Qi Z, Dong D, Yang H, Xia X (2017) Improving fermented quality of cider vinegar via rational nutrient feeding strategy. Food Chem 224: 312-319.

7. Hardisson A, Rodríguez MI, Burgos A (2003) Encyclopedia of Food Sciences and Nutrition. Academic Press, Amsterdam, Netherlands.

8. Jáudenes JR, Hardisson A, Gutiérrez AJ, Rubio C, Revert C (2015) Evaluación del riesgo tóxico por la presencia de fluoruro en aguas de bebida envasada consumidas en Canarias. Nutr Hosp 32(5): 22612268.

9. Paz S, Jaudenes JR, Gutiérrez AJ, Rubio C, Hardisson A, et al. (2017) Determination of Fluoride in Organic and Non-Organic Wines. Biol Trace Elem Res 178(1): 153-159.

10. Cuervo M, Corbalán M, Baladía E, Cabrerizo L, Formiguera X, et al. (2009) Comparativa de las ingestas dietéticas de referencia (IDR) de los diferentes países de la Unión Europea, de Estados Unidos (EEUU) y de la Organización de la Salud (OMS). Nutr Hosp 24(4): 4384-4414.

11. IOM (Institute of Medicine) (2004) Food and Nutrition Board. Dietary reference intakes (DRIs): Recommended Intakes for Individuals, Elements. National Academy Press, Washington DC, USA.

12. García G, Lapa RAS, Lima JLFC, Pérez-Olmos R (1992) Determination of fluoride in Spanish vinegars. Food Chem 45(5): 365-367.

13. Lapa RAS, Lima JLFC, Pérez-Olmos R, Ruiz MP (1995) Simultaneous automatic potentiometric determination of acidity, chloride and fluoride in vinegar. Food Control 6(3): 155-159.

14. Bernal JL, del Nozal J, Pardo R (1979) Determinación de fluoruros en vino. Rev Agroquim Tecnol Aliment 19(4): 541-548.

15. De Baenst G, Mertens J, Vandenwinker P (1973) Détermination de l'ion fluorure dans le vin, par potentiométrie. J Pharm Belg 28: 188-194.

16. Deschreider A, Meaux R (1974) Détermination du fluor dans les vins et les eaux minérals naturelles au moyen d'une électrode ionique spécifique. Rev Ferment Ind Aliment 28: 150-156.

17. Hardisson A (1996) Proyecto de investigación de la Consejería de Sanidad y Consumo titulado "Estudio de las concentraciones de fluoruro en aguas y vinos de las Islas Canarias. Evaluación de los efectos toxicológicos de su consumo", Resolución de 26 de agosto de 1996. Boletín Oficial de Canarias, Spain 119: 8619-8623.

18. Hidalgo JL, Pastor M, Pérez-Bustamante JA (1983) Determinación de fluoruro en vinos del Marco de Jerez. Anal Bromatol 35: 67-77.

19. Martínez Rincón MC, Abuín Cabeza LM (1990) Flúor en vinos de denominación de origen méntrida. An RAcad Farm 56: 279-282. 
20. Pérez-Olmos R, Hardisson A, Elias M, Rios R, Martín M (1990) Determination of fluoride in Tenerife wines. Comparative study of conditioning solutions. Belg J Food Chem Biotechnol 45(6): 208-213.

21. Pérez-Olmos R, Herrero R, Lima JLFC, Lopes TIMS, Rangel AOSS (1995) Bibliographic study of potentiometric methods of wine and must analysis. Journal international des sciences de la vigne et du vin 29(3) 159-169.

22. Rodríguez Gómez MI (2015) Determinación potenciométrica de fluoruros en aguas y en algunos alimentos líquidos. Cálculo de la ingesta por parte de la población canaria. Tesis Doctoral, Universidad de La Laguna, Spain.
23. Martín C, Brun S (1969) Le dosage du fluor dans les vins. Trav Soc Pharm de Montpellier 29(3): 161-167.

24. Moreno F, De la Torre MC, Serrat M (1971) Un electrodo específico para la determinación de pequeñas cantidades de ion fluoruro. Circ Farm 29: 315-331.

25. U.S Department of Agriculture (2005) USDA National Fluoride Database of Selected Beverages and Foods Release 2, USA.

26. Qi Z, Dong D, Yang H, Xia X (2017) Improving fermented quality of cider vinegar via rational nutrient feeding strategy. Food Chem 224: 312-319.

\section{Your next submission with Juniper Publishers will reach you the below assets}

- Quality Editorial service

- Swift Peer Review

- Reprints availability

- E-prints Service

- Manuscript Podcast for convenient understanding

- Global attainment for your research

- Manuscript accessibility in different formats

( Pdf, E-pub, Full Text, Audio)

- Unceasing customer service

Track the below URL for one-step submission https://juniperpublishers.com/online-submission.php 